\title{
Fiscal Policy and External Shocks in Nigeria
}

\author{
Patrick Ologbenla \\ Federal Inland Revenue Services, Abuja, Nigeria \\ ologbenlapatrick@gmail.com
}

\begin{abstract}
The study assessed the effects of external shocks on fiscal policy in Nigeria. Vector auto-regression VAR estimating technique is adopted to achieve the set objectives of the study. The VAR model comprises of the following variables GDP, oil output, oil price, government revenue, government expenditure, external reserve, exchange rate, fiscal balance, and non-oil export. These variables represent the external shocks, the growth variables, fiscal variables and some other macroeconomic variables. The VAR results show that oil price and non-oil export are the most important external shocks affecting fiscal policy in Nigeria. It was also discovered that public debt shock has no significant impact on government expenditure. In addition, external reserve and exchange rate shocks also have a significant impact on fiscal policy. Finally, government expenditure shock failed to have a significant impact on the GDP. The implication of these results is that the effectiveness of fiscal policy in achieving macroeconomic objectives in Nigeria depends on these identified shocks.
\end{abstract}

Keyword: External Shocks, Fiscal Policy, Government expenditure.

\section{Introduction}

Over the years the fiscal policy has been a major policy used side by side monetary policy to maintain economic stability, increase output and promote the overall economic development of a country. However, attention of researchers in recent times have been more driven towards fiscal policy and one of the reasons for this is the general consensus that monetary policy only has a transitory effect on output (Tobins 1965, Sidrauski 2003, Papademous 2008). In other words, fiscal policy has been identified as a policy that tends to have long-run relationship with growth. However, there is a general belief that such policy will be highly susceptible to external influences which might mitigate it's having a sustainable effect on output over the long run period horizon it is designed for (Olasunkanmi, 2013). Two major variables of fiscal policy that is, the government revenue and expenditure have been identified to be highly prone to external influence especially in a country that is naturally endowed and heavily dependent on imported goods (World Bank, 2012). The nature of fiscal policy practiced in Nigeria for the past two decades has been in the form of deficit. That is, a major feature of fiscal policy in Nigeria over the years has been fiscal deficits.

Although the democratically elected government in 1999 adopted policies to restore fiscal discipline, the rapid monetization of foreign exchange earnings between 2000 and 2004, another era of oil windfall, resulted in large increases in government spending. In 2005 alone, government spending increased to 19 percent of GDP from 14 percent in 2000. Extra-budgetary outlays not initially included in the budget increased. Worst till, most of this spending is not directed towards capital and socio-economic sectors (CBN, 2009). As a Corollary, primary deficit worsened from an average of 2.6 percent of GDP in 1980s to 6.2 percent in 1990s. In 2002 alone, primary deficit increased to 5 percent of GDP from 2 percent in 2000. This increase in deficits results in a mounting stock of debt, ranging from 88 percent of GDP in 1980s to 96 percent of GDP in 1990s. More recently in 2010 alone, the stock of debt increases to 91 per cent of GDP from 45 per cent in 2009. According to Obinyeluaku (2009), for the past two decades, Nigeria has witnessed a considerable increase in government indebtedness beyond the issue of poor quality of public expenditure.

The ability to save windfalls from excess crude oil proceeds by the government remains critical in ensuring that government expenditure is maintained at a sustainable level that is consistent with the absorptive capacity of the economy. According to him, there has been a substantial increase in government spending, primary deficit and debt in Nigeria between 1996 and 2009. However, it has been observed that despite the huge fiscal deficit that characterize fiscal policy administration in Nigeria, the overall economy appears not to have fared very well during these periods and this has constituted a major concern to the policy makers (Olasunkanmi, 2013). Because around the period when the government was witnessing an upsurge in government expenditure which resulted in a fiscal deficit, the real GDP growth rate fell from $-3.1 \%$ in 2007 to 
$-7.6 \%$ in 2009 (World Bank 2012). The implication of this is that the accumulated fiscal deficit has not reflected in growth of Nigeria during these periods.

Furthermore, the vulnerability of many resource-endowed countries to external cyclical influence has been identified as a major cog in the wheel of progress of these countries in that; it inhibits positive synergy between policies and economic development. Consequently, World Bank Economic Reports on Nigeria in 2013, precisely in the appraisal of Nigeria economic overview and performance among others have clearly stated that there is the need to identify external factors that affect domestic policies as well as an examination of the behaviours of such policies to these external influences. This is believed will lead to the evolvement of the framework that will create enabling environment for these domestic policies to begin to yield positive impacts on economic development (see Capistran and Cuadra, 2011; Ball, 2000; Clements, Flores and Leigh, 2009). For instance, Nigeria which is an oil-rich country has her fiscal revenues to be largely coincided with oil revenue. Oil revenue accounts for nearly 80 percent of government revenues, which implies that the economy is highly exposed to price fluctuations in the world oil markets. Naturally, oil revenue is very volatile due to world oscillation in oil prices and to unpredictable changes in OPEC assigned oil quota - of which Nigeria has been a member since 1958 (Obinyeluaku 2009).

However, apart from oil-related variables, some other factors which are mostly macroeconomic variables also constitute shocks to fiscal policy. Many of these variables which vary from country to country have been identified by quite a number of researchers as external factors that might likely cause perturbation of fiscal policy variables and which can limit its influence on the economic development of a particular country (Kinnunen, Sulla and Merotto, 2013; Gosse and Guillamin, 2012). Based, on the foregoing, it appears that making the effect of fiscal policy felt positively on Nigerian economic development can be facilitated through identification of these external factors as well as studying the behavior of fiscal policy variables to them. This, according to the World Bank and other researchers identified above, will lead to restructuring in both formulation and implementation of fiscal policy so as to improve its contributions to the economic development of Nigeria (Obinyeluaku and Viegi, 2012). Consequently, the main objective of this study is to investigate the effects of external shocks on fiscal policy in Nigeria. The rest of the paper is as follows; the methodology, results and discussion, conclusions and recommendations.

\section{Methodology}

The model's specification, definition of variables, method of analysis and sources of data are discussed under this section

The Model: Barro and Sala-i-Martin $(1992,1995)$ have developed a series of models, in which investment in infrastructure affects output through the production function, as a factor along with capital and labour, in order to study the influence of the supply of public goods on growth rates. Clearly, the rate of output growth can be positively related to the share of government purchases, in the form of public services, while examining various policy implications under alternative schemes of the production function. Consequently, government expenditure in the form of public investment plays a decisive role in the performance of the economy through its influence on gross national output. Several empirical studies have also established a strong positive link between investment and output growth rates; Aschauer (1989), Baxter and King (1993), Easterly and Rebelo (1993), Dollar and Svensson (2000), and Bekaert et al. (2005).

According to Barro (1992) and Lucas (1988) in an economy that embraces a large number of competitive firms without loss of generality and aggregating across firms, the production function may be given in the following expression;

$\mathrm{Y}=\mathrm{AK}^{a}(\mathrm{hL})^{1-a}$

Where: $\mathrm{Y}$ denotes output, $\mathrm{K}$ is capital, and $\mathrm{L}$ stands for labour, with $\alpha$ and 1- $\alpha$ being the shares of capital and labour, respectively. Parameter A reflects the constant technology level, with $A>0$. According to Lucas (1988) the assumption of constant returns becomes more plausible whenever, as in our case, capital is broadly viewed to encompass both human and physical capital. Indeed, parameter $\mathrm{h}$ represents human capital and is 
considered to be a function of the existing total (private and public) capital of the economy, denoted by K and $\mathrm{G}$ respectively, so that;

$h=\psi \frac{K^{\beta} G^{1-\beta}}{L}$

Where: $\psi>0$ stands for an efficiency parameter that captures the degree of the economy's efficiently used total capital. G represents the aspect of supply of capital through government expenditure. Substituting equation 2 into 1 we have:

$Y=A K^{\alpha}\left(\psi \frac{K^{\beta} G^{1-\beta}}{L}\right)$

Note that both $\alpha$ and $\beta$ are the same being elasticities of the respective inputs. Through factorization we can rewrite equation 3 as follows;

$Y=A K^{\alpha}\left(\psi \frac{G^{1-\alpha}}{L}\right)$

Where $\frac{G^{1-\alpha}}{L}$ denotes governments expenditure adjusted to the workforce population.

Re-arranging equation 4 we have the following;

$Y=A \psi K^{\alpha}\left(\frac{G^{1-\alpha}}{L}\right)$

Since both $A$ and $\psi$ are efficiency parameters we denote the product by $\sigma$ giving rise to;

$Y=\sigma K^{\alpha}\left(\frac{G^{1-\alpha}}{L}\right)$

Equation 6 can be re-arranged as;

$Y=\sigma K^{\alpha}\left(\frac{1}{L} G^{1-\alpha}\right)$

Linearising equation 7 through log we have;

$\log Y=\log \sigma+\alpha \log K+(1-\alpha) \log \frac{1}{L} G$

Equation 8 is adopted in this study to examine fiscal policy impact on the output of Nigeria. The components of the equation are GDP which is $\mathrm{Y}, \mathrm{K}$ is the gross capital formation and the fiscal component is represented with G i.e. government expenditure. However, since government expenditure is strongly linked with Fiscal deficit/surplus, G is proxy by $\mathrm{Fd} / \mathrm{Fs}$ that is a fiscal balance.

Vector-Auto Regression (VAR) Model: Econometrics literature has identified VAR as a veritable means of studying the effect of shocks on an economic variable in both short and medium terms (Elbourne, 2007; Adebiyi, 2010). Formulation of the VAR model is strongly dependent on shocks identification in the VAR model and this often depends on the objectives of the researcher as well as literature. In this study, we are interested in studying shocks effects on fiscal policy and the resultant implication on the output of Nigeria. In other words, we are looking at how fiscal policy is acting as the transmission mechanism of the external shocks affecting it to the output growth of Nigeria. From literature oil price, oil output, external reserve, national debt, non-oil export volume and exchange rate have been identified by Capistran and Cuadra, (2011); Ball, (2000); Clememnts, Flores and Leigh, (2009) among others as external factors that can influence fiscal policy in Nigeria which is an oil-rich country. Fiscal variables used as transmission mechanism are government revenue, government expenditure, Fiscal deficit /surplus. And the output variable is the GDP. VAR models are seen as independent large scale macro-econometric model that do not rely on unrealistic assumptions (Elbourne, 2007). The most theoretical framework of VAR analysis as proposed by Sims (1980) used Cholesky decomposition to get impulse responses.

The construction of our VAR model follows the conventional method where the initial model is specified thus: $y_{t}=A_{1} y_{t-1}+A_{2} y_{t-2}+, \ldots \ldots \ldots .+A_{p} y_{t-p}+\mu_{t}$

Where:

$y_{t}$ Represents an (nx1) vector containing $\mathrm{n}$ endogenous variables,

$A_{i}(i=1,2, \ldots . p)$ are $(\mathrm{n} \times \mathrm{n})$ matrices coefficients,

And $\mu_{t}$ is an ( $\left.\mathrm{n} \times 1\right)$ vector containing error terms.

Though the error is $\mu_{t} \sim$ iid $N(0, \Omega)$ but errors do possess tendency of correlating contemporaneously in all the equations.

There exist $p n^{2}$ Parameters in the A matrices. Equation 3.9 can be written in other form with the usage of the lag operator $L$ which is selected through $L^{k} x_{t}=x_{t-k}$. the equation becomes: 
$A(L) y_{t}=\mu_{t}$

Where:

$A(L)=A_{0} L^{0}-A_{1} L^{1}-A_{2} L^{2}-\cdots \ldots \ldots-A_{p} L^{p}$.

$A_{0}=$ I (identity matrix) it is required that $A(L)$ lies outside the unit circle for stationarity to be ensured.

The VAR model estimated for the purpose of this study is as follows;

$G D P_{t}=\left[\right.$ oilpr $_{t}$, oilout $_{t}$, extr $_{t}$, exr $_{t}$, debt $_{t}$ nexp $_{t}$, govrev $_{t}$, govexp $\left._{t}, f s / f d_{t}\right]$

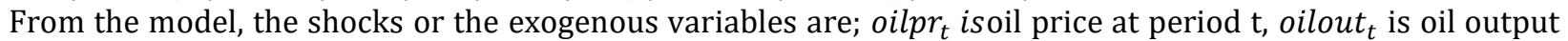
at period t,extr ${ }_{t}$ is Nigeria external reserve at period t, exr $r_{t}$ is Exchange rate at period $\mathrm{t}$, debt $_{t}$ is Public debt at period $t, \exp _{t}$ is Non oil export volume at period $t$. The fiscal policy variables that act as transmission mechanism are; govrev $_{t}$ is Government revenue at period $t$, govexp $_{t}$ is Government revenue at period $t$, $f s / f d_{t}$ is Fiscal balance at period t. The output variable is $G D P_{t}$ is the GDP gross domestic product of Nigeria at period $t$. Both the impulse response function and the variance decomposition analysis is done to thoroughly examine the response of the fiscal variables to the identified shocks and also to assess the resultant effect on output growth of Nigeria.

Sources of Data: Data on the fiscal variables and the output variable from 1980-2015 are sourced from the Central Bank statistical bulletin (2016). While data on the variables relating to oil especially oil price and oil output will be sourced from the OPEC database.

\section{Results and Discussion}

Non Stationarity: This study follows the work of (See Uhlig, 2005; Peersman and Smets, 2005; Vonnak, 2005; Clements \& Hendry, 1995; Fève and Guay, 2006; Ibrahim and Amin, 2005) among others where levels VAR are used. The authors argued that this will prevent loss of some vital information about the data sets which might occur in the course of differencing. However, it has also been argued that the inclusion of lagged lengths of the variables in the VAR will enable the residual to be stationary even with a non stationary series that isI(1) (see Beckelmans, 2005). Many study in recent times have also followed the same procedure (see Ngalawa and Viegi, 2011; Elboure, 2008; Mordi and Adebiyi, 2010; Mahmud, 2009) among others.

Impulse Response Results: The impulse response analysis of the relationship between external shocks and fiscal policy in Nigeria is based on the five identified external shocks namely; oil price, debt, non-oil export, external reserve and exchange rate. First, we consider the reactions of the variables to shock from each of the identified external shocks, in other words, the spiral effects of the shocks emanating from oil price, debt, nonoil export, external reserve and exchange rate is examined as it affects fiscal policy variables and the GDP. Secondly, in the same perspective, we also assess the responses the GDP which proxy for Nigeria economic growth to the shock emanating from the fiscal variables namely; total government revenue, total government expenditure and fiscal balance.

\section{Figure 1: Impulse Response to Oil Price Shock}

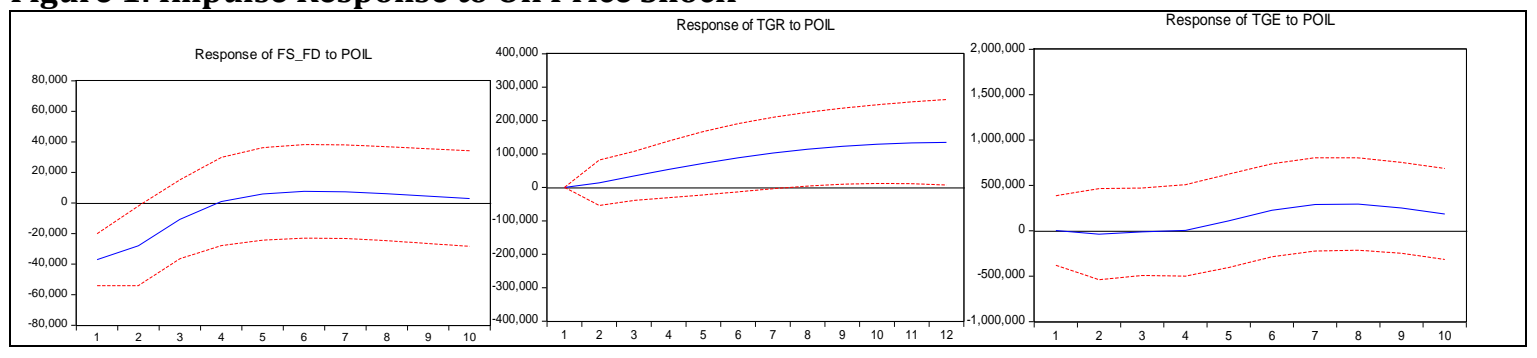




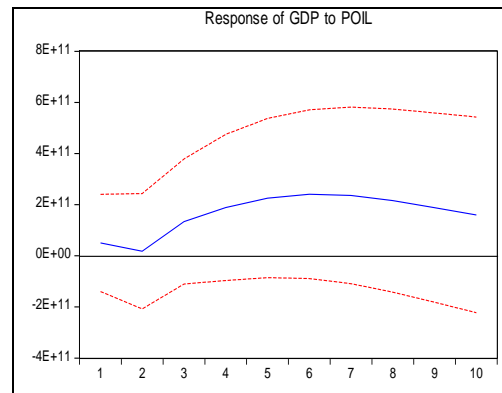

The response of the fiscal variables to one standard deviation shock in oil price is shown in figure 1. One standard deviation shock depicts a sudden rise. The response of the government revenue TGR appears to be most positive in all the responses. In other words, total government revenue exhibit a positive and significant response to the shock from oil price though it was not all that significant at the beginning of the period but as the period progresses specifically at the fourth period, positive response becomes more pronounced and significant. However, the responses from the remaining fiscal policy variables namely; government expenditure and fiscal balance is also positive but not all that significant. The same behavior is also noticed in the response of the GDP to the oil price shock. The implication is that despite the significant and positive impact that the oil price shock has on the government revenue it appears that the effect is not transmitted significantly to both government expenditure and the GDP.

\section{Figure 2: Impulse Response to Debt Shock}

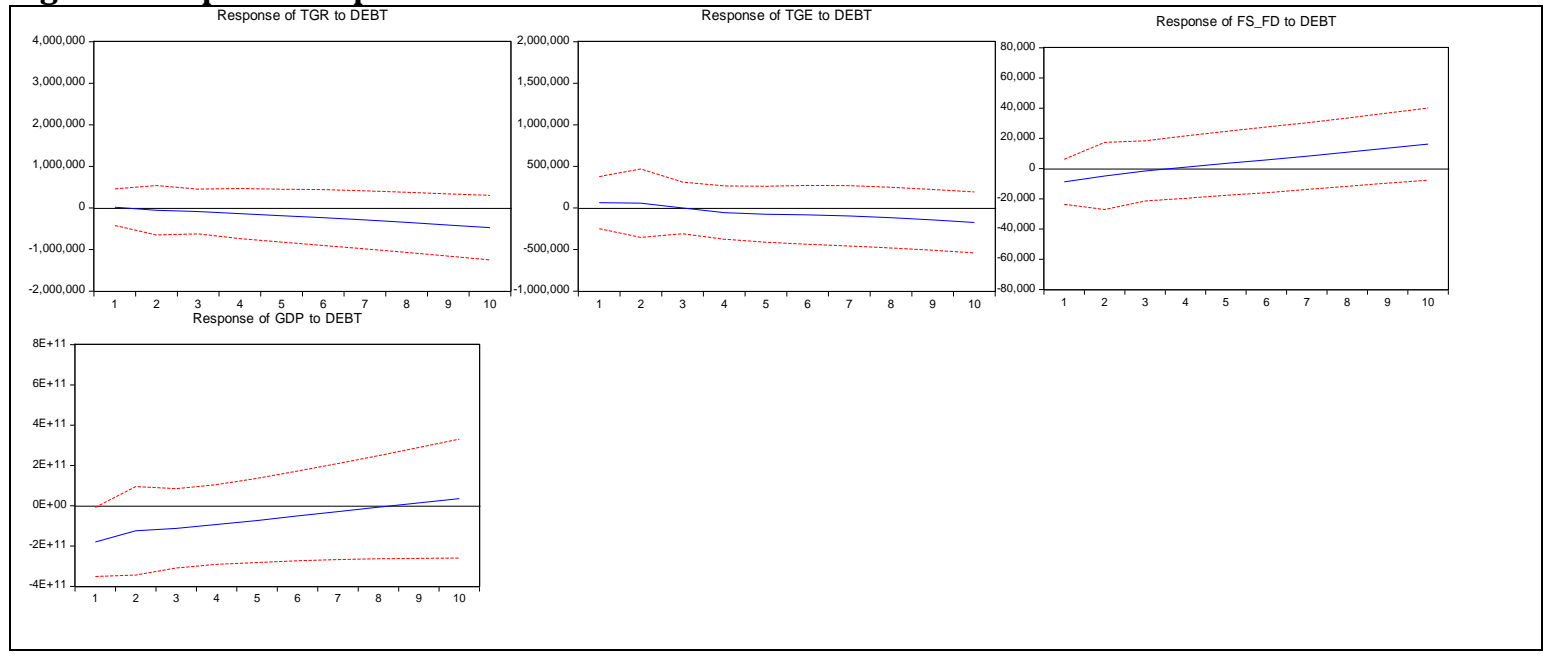

Figure 2 indicates that both government revenue and government expenditure display a downward response to a shock from debt. It is very apparent from the figure that whenever there is a shock (a sudden rise) in the national debt of Nigeria, it will have a falling impact on government revenue though the effect is not significant. In the same vein government expenditure also follows that same reaction to shock from debt. This is contrary to apriori expectation. It is believed that debt should increase the expenditure of the government in s away that it will promote output. Though the debt shock does have a positive impact on the fiscal balance and the GDP they are also not significant. The overall implication is that despite the sudden rise in debt, the effect is not significant on the GDP of Nigeria. Figure 3 explains the responses of the fiscal variables to one standard deviation in non-oil export. The result indicates that government revenue firstly showed a falling reaction before picking up in the $2^{\text {nd }}$ period. This rise is sustained through the remaining periods. It should also be noted that the response is also significant. 


\section{Figure 3: Impulse Response to Non-Oil Export Shock}

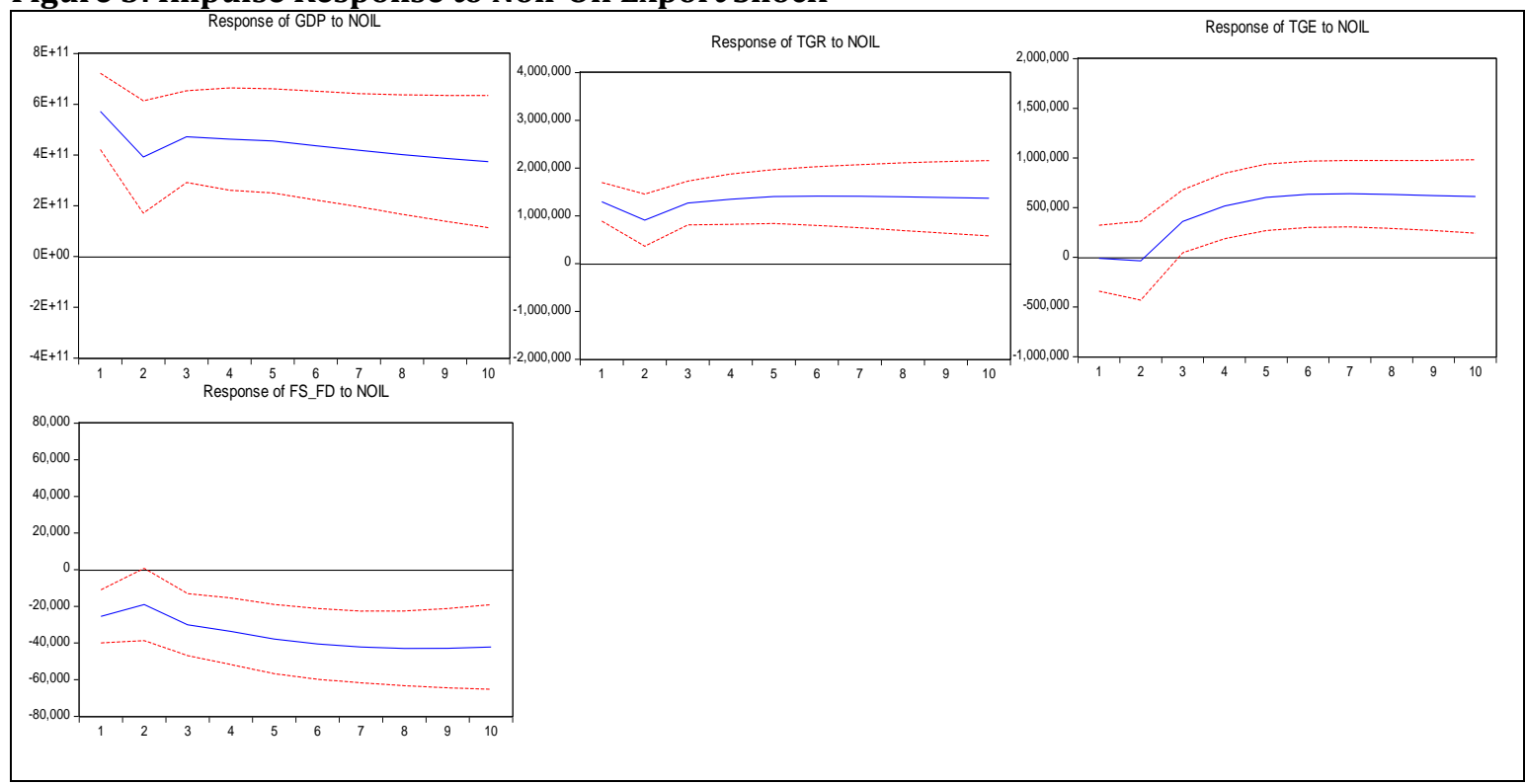

In the same vein, the response of government expenditure is also significantly positive. The same response is exhibited by the GDP in response to the chains of reaction from government revenue and expenditure. All of these responses are significant. However, the fiscal balance still ends up in significant deficit despite the positive effects the shock has on government revenue.

Variance Decomposition: Variance decomposition explains the percentage or unit response of each variable in our model to the different structural shocks. In other words, we try to explain the contribution of various structural shocks on government revenue, government expenditure, fiscal balance and gross domestic product GDP.

Figure 4: Impulse Response to Exchange Rate Shock

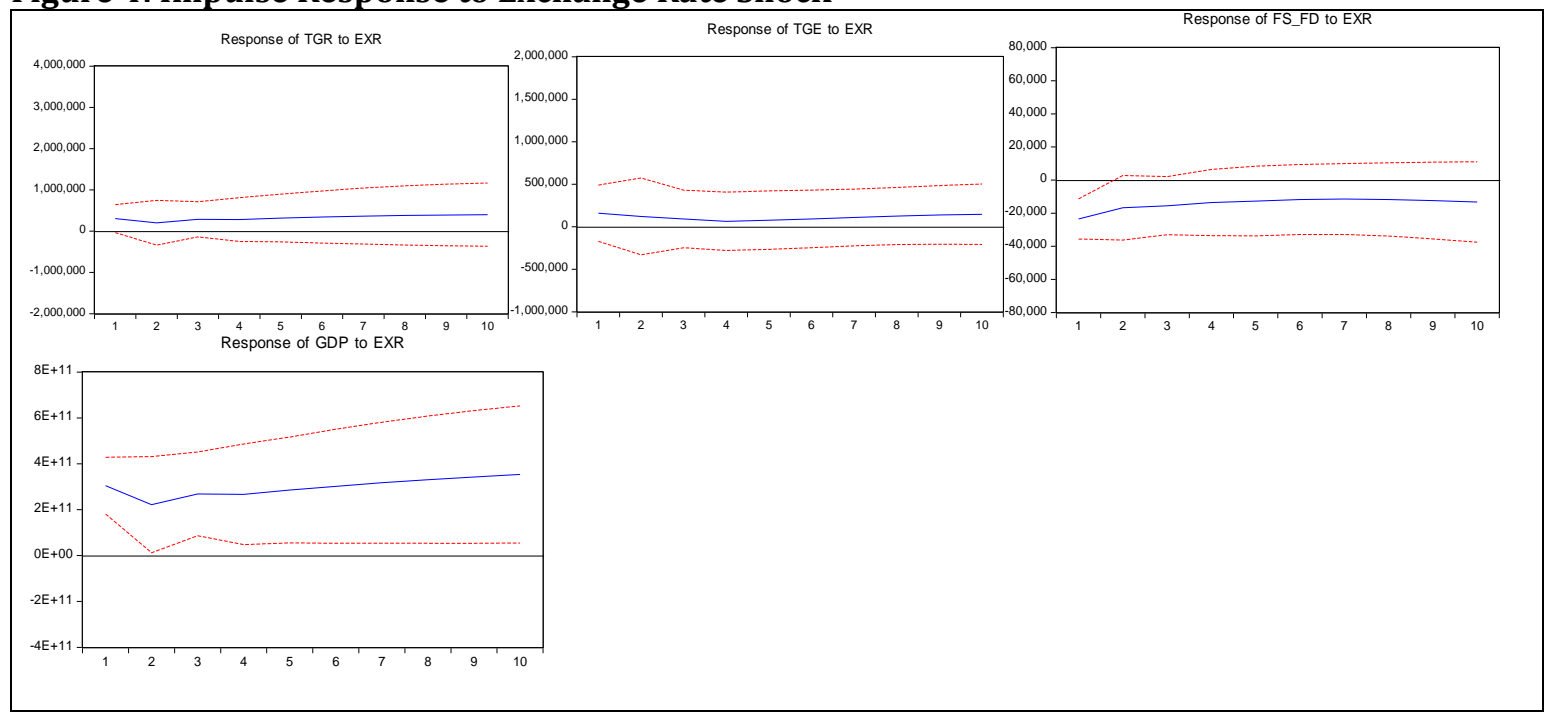

The responses of the variables to one standard deviation in the exchange rate are shown in figure 4. The result shows that the shock has a positive impact on both the fiscal variables and the GDP. But the response of the GDP is significant. This shows that currency appreciation is inimical to the growth of Nigeria. The results have contributed to the growing literature that discourages over-valuation of currency especially in a 
resource-endowed country like Nigeria. In addition, the shock also has a positive implication on all the fiscal variables. Though, the effect might not be as significant as its impact on the GDP which is the proxy for economic growth. Figure 5 indicates the responses of the variable to one standard deviation in the external reserve.

\section{Figure 5: Impulse Response to External Reserve Shock}

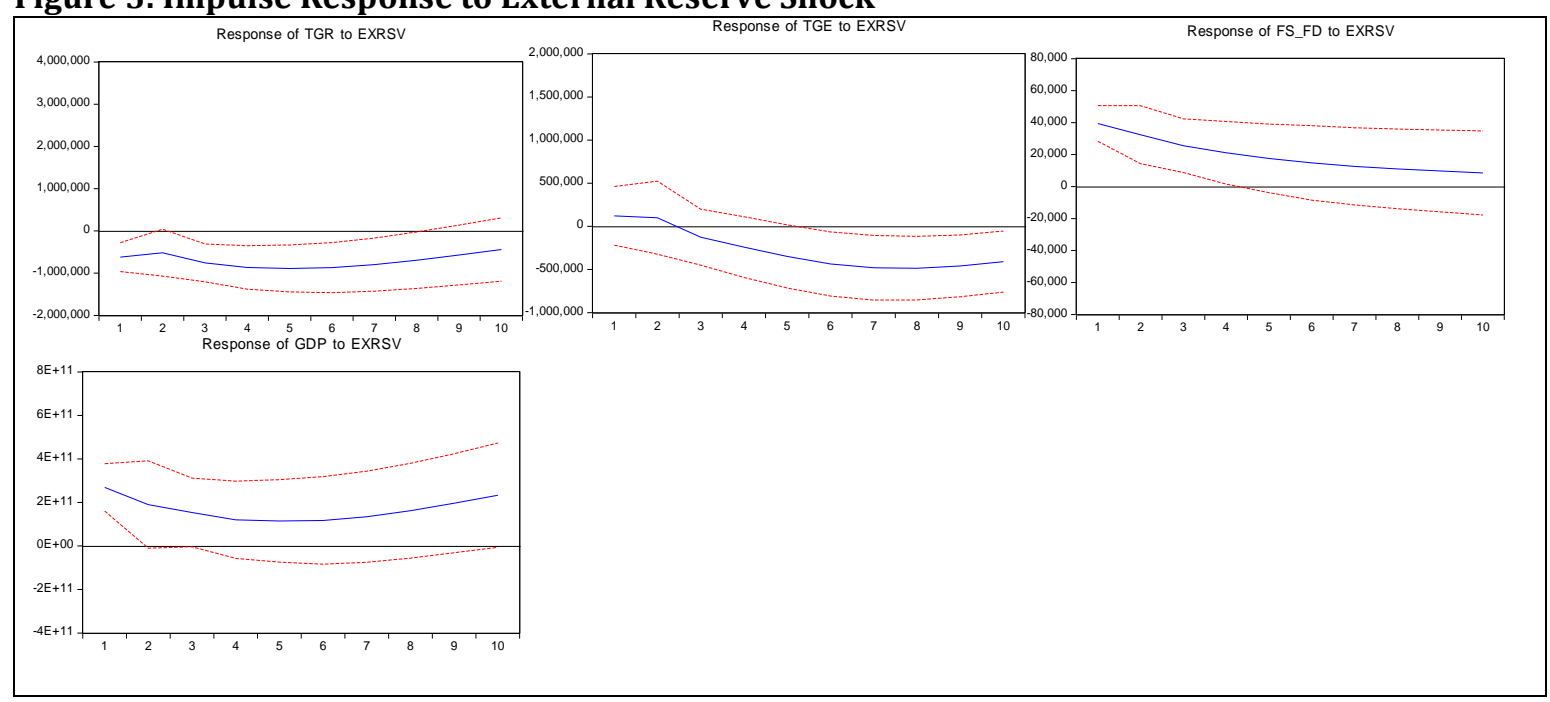

The shock emanating from the external reserve appears not to have a positive effect on the fiscal variables. It is noted from the diagram that the shock makes both government revenue and expenditure to fall significantly. Though at the $6^{\text {th }}$ period they appear to be picking up but yet they are still below the zero line margins. Fiscal balance also falls entering deficit gradually. It has a decreasing effect on the GDP very briefly and initially but picks up at the fourth period and no longer significant.

Table 1: Variance Decomposition of Total Government Revenue

\begin{tabular}{llllll}
\hline Period & Poil & Debt & noil & exr & Exrsv \\
\hline 3 & 15.35997 & 0.088590 & 34.01672 & 1.781659 & 10.12381 \\
6 & 16.33588 & 0.517571 & 43.66666 & 2.260647 & 15.54031 \\
9 & 15.36709 & 1.494098 & 48.30123 & 2.891313 & 15.21828 \\
12 & 14.21673 & 3.247708 & 51.27826 & 3.474700 & 12.81877 \\
\hline
\end{tabular}

Table 1 shows the contributions of each structural shock to the behaviour of government revenue in Nigeria. The result shows that the price of oil and non-oil exports appear to be the largest shocks that affect the behaviour of government revenue. They both contribute the largest percentage of shock to the total shock received by government revenue in Nigeria. Exchange rate and debt appear to be the least contributors of shock to government revenue. This underscores the significance of oil price and non-oil export in determination of government revenue in Nigeria.

Table 2: Variance Decomposition of Total Government Expenditure

\begin{tabular}{llllll}
\hline Period & Poil & Debt & noil & exr & Exrsv \\
\hline 3 & 0.024660 & 0.118103 & 2.118075 & 0.781862 & 0.652104 \\
6 & 0.730369 & 0.259634 & 13.12963 & 0.758009 & 4.631243 \\
9 & 2.629646 & 0.582932 & 20.75238 & 1.006402 & 9.567669 \\
12 & 2.575933 & 1.458512 & 25.59125 & 1.334544 & 10.72387 \\
\hline
\end{tabular}

From table 2 external reserves joins non-oil export as two important shocks that influences government expenditure. Though oil price is the next, comparatively non-oil export and external reserve affect government expenditure more than oil price. 
Table 3: Variance Decomposition of Fiscal Balance

\begin{tabular}{llllll}
\hline Period & Poil & Debt & noil & exr & Exrsv \\
\hline 3 & 15.23042 & 0.691176 & 12.77599 & 7.186850 & 21.82580 \\
6 & 9.720577 & 0.612193 & 25.10277 & 6.389256 & 17.37220 \\
9 & 7.415504 & 1.552374 & 34.63209 & 5.920514 & 13.78315 \\
12 & 5.967948 & 3.748731 & 39.80784 & 6.179501 & 11.41201 \\
\hline
\end{tabular}

The dominance of oil prices external reserve and non-oil export continues as important shocks that affect fiscal policy variables. While oil price and external reserve have the highest impact in the first quarter there, impact starts falling and non-oil export shock contributions start rising from the second quarter. The implication of these results is that the behaviour of fiscal policy variables is highly influenced by the three.

Table 4: Variance Decomposition of GDP

\begin{tabular}{llllllll}
\hline Period & Poil & debt & Noil & Exr & Exrsv & Tgr & Tge \\
\hline 3 & 1.261686 & 3.667494 & 42.76191 & 13.00275 & 8.025662 & 24.06511 & 0.805798 \\
6 & 5.668131 & 2.635668 & 45.10649 & 15.69570 & 5.948408 & 14.56438 & 1.573792 \\
9 & 7.227572 & 1.860222 & 42.99664 & 18.73924 & 6.113010 & 10.19785 & 1.221826 \\
12 & 6.544059 & 1.610279 & 39.91907 & 21.52687 & 8.659550 & 7.793295 & 0.963117 \\
\hline
\end{tabular}

The GDP is a proxy for economic growth and table 4 shows its behaviours to both the fiscal policy shocks and the identified external shocks. The result indicates that exchange rate which appeared to be inactive in the previous discussions on variance decomposition appears to be an important shock to economic growth. The situation corroborates the reaction of the GDP to the shock from exchange rate as explained in the impulse response analysis. It was shown under the impulse response result that over-valuation of naira will definitely have a significant adverse effect on the output GDP. The variance decomposition of the GDP is following the same results. Exchange rate, non-oil export is the most important shock dictating the behaviour of the GDP. Among the fiscal policy variables, government revenue contributes the highest shock to the behaviour of the GDP.

\section{Conclusion and Recommendations}

Findings from the study have shown that government revenue among the fiscal variables is mostly affected by external shocks. This is followed by government expenditure and fiscal balance in that order. Oil price shock and non-oil export shock are the most important shocks affecting government revenue. Notwithstanding, positive and significant influence of oil price shock on government revenue appears not to have reflected on the GDP because the shock fails to produce any significant impact on the GDP. In support of this, variance decomposition result shows that government revenue does not have a sustainable, significant influence on the GDP. This is similar to the findings of Usenobong and Johnson (2015) who concluded that several funds released by the Nigerian government for investment purposes have failed to have an impact on the economy.

Again, the non-oil export shock is the most important shock affecting government expenditure. Other shocks that affect government expenditure immensely is the external reserve. The power of the government to spend appears to be affected whenever there is a rise in external reserve. The result also shows that debt shock has not significantly increased government expenditure. The implication is that government borrowings appear not to have reflected in the government expenditure in Nigeria. This is an indication that the debt incurred by the Nigerian government might not have been used for productive expenditures. Moreover, non-oil export is the only shock that might positively influence the expenditure of the government. Fiscal balance is mostly affected by external reserve shock and non-oil export shocks. External reserve shock is likely going to lead to a fiscal deficit. This is noted from the Nigerian economy were for most of the past two decades the external reserve has been rising and yet deficit budgeting still take preeminence in the country's fiscal policy practice.

The reverse of this action is produced by the non-oil export shocks. The GDP is also mostly influenced by the non-oil export shock and exchange rate shock. The government revenues shock fails to produce a sustainable effect on the GDP. While government expenditure shock has very little effect on the GDP. Importantly, the 
findings from the study have supported the growing literature on the adverse effect of over-valuation of currency on the growth of a country. The study has shown that if Nigeria Naira is over-valued, it will have adverse implications on the GDP. In other words, it will affect local production especially from the tradable sector/real sector of the economy and by implication, it will affect the growth of the economy. Finally, the dominance of the non-oil export shock can be explained within the framework of VAR. Vector auto-regression impulse response analysis and the variance decomposition explains the effect of one standard deviation of a shock on a variable.

The implication here is that a sudden upsurge in the non-oil export is capable of improving government revenue, government expenditure and the gross output (GDP) significantly. The findings from the study are also supporting the growing literature advocating diversification of economy as a panacea for the economic woes of resource-endowed country like Nigeria. For instance, among 65 countries that can be classified as natural resources-rich, only Botswana had long term investment exceeding 25\% of its GDP between 1970 and 1998 and also recorded GNP per-capita growth exceeding 4\% in a year(see Olomola, 2006; Gylfason, 2001). The major reason for the success of this economy was its ability to effectively diversify through accelerated growth in the domestic output which was made possible through a vibrant non-oil sector (Olomola, 2006).

Policy Recommendations: Following the findings and the conclusions from the study, some course of actions might be necessary for Nigeria. This course of actions will definitely improve the economic gains of Nigeria from fiscal policy practice even in the realities of the external shocks.

- Diversification of the economy: Several studies in the past have advocated economic diversification as a good solution to the lopsidedness in the growth of the oil-rich countries and other resourceendowed countries. Nigeria which also belongs to this group of countries can benefit more from her fiscal practice if the economy is diversified.

- Funding of the non-oil sector: Findings from the study have shown what non-oil export is capable of doing. The real sector of the economy should be funded by the oil proceeds; these include the industrial sector especially the manufacturing and the agricultural sectors. This sector is capable of preventing the fiscal variables from been adversely affected by the external shocks.

- Encouraging fiscal prudence: Government revenues shocks fail to produce a sustainable positive influence on the GDP. This shows that government revenue has not been efficiently utilized to promote the economic growth of Nigeria. This is where corruption, embezzlement, fund diversion among others are evident.

- Encouraging competitive exchange rate: Pegging of exchange rate should be discouraged. Excessive valuation of currency or appreciation of currency might adversely affect gross output. The real sector of the economy might not be able to cope with such an exchange rate and this might lead to a decline in domestic output.

- Limit in debt accumulation: Excessive public debt might be inimical to the growth of Nigeria. The study has shown that none of the variables responds positively and significantly to debt shock. This includes the GDP. Therefore effort must be made to reduce public debt as much as possible since it has not significantly influenced the gross output of Nigeria.

\section{References}

Barro, R. G. \& Sala-i-Martin. (1992). Public finance in models of economic growth, Review of Economic Studies, 59, 645-661.

Ball, L. (2000). Policy rules for open economies. In J. B. Taylor (Ed.), Monetary policy rules, pp. 127.156. Chicago: University of Chicago Press for NBER.

Becklemans, L. (2005). Credit and monetary policy: Australian SVAR. Reserve Bank of Australia Research Discussion Paper Series, 1, 2-9.

Capistran, C. \& Caudra, G. (2011). Policy response to external shocks: Lesson from the crisis. Documento-de Investigation Working paper 2011-14. 
Central Bank of Nigeria (CBN) Statistical Bulletin (2016). Edition.

Central Bank of Nigeria (CBN). (2009). Statistical bulletin golden Jubilee Edition. Abuja: CBN.

Clements, M. P., Leign, H. \& Flores, D. F. (2009). Forecasting in cointegrated systems. Journal of Applied Econometrics, 10(5), 127-146.

Clements, M. P. \& Hendry, D. F. (1995). Forecasting in cointegrated systems. Journal of Applied Econometrics, $10(5), 127-146$.

Easterly, W. \& Rebelo, S. (1993). Fiscal policy and economic growth: An empirical investigation, Journal of Monetary Economics, 32, 417-458.

Elbourne, A. (2007). The UK housing market and the monetary policy transmission mechanism: An SVAR approach. Journal of Housing Economics, 17(2008), 65-87.

Fève, P. \& Guay, A. (2006). The response of hour to technology shock: SVAR approach. Money Credit bank, $5(1), 958-1103$.

Gelb, A. H. (1988). Oil windfalls: blessing or curse, Oxford University Press (for World Bank), Oxford.

Gosse, M. T. \& Guillamin, L. Y. (2012). Will natural gas prices decouple from oil prices across the pond? IMF working paper, WP/11/143.

Gylfason, T. (2001). Natural resources, education, and economic development. European Economic Review, 45, 847-59.

Ibrahim, H. M. \& Amin, M. R. (2005). Exchange rate, monetary policy and manufacturing output in Malaysia. Journal of Economic Cooperation, 26(3), 103-130.

Kinnunen, J., Lofgren, H., Victor Sulla. \& Dino Merotto. (2013). External shocks, fiscal policy and income distribution: alternative scenarios for Moldova. World Bank Policy Research Working Paper 6365.

Lucas, R. (1988). An equilibrium model of the business cycle. Journal of Political Economy, 83, 1113-1144.

Mahmud, H. (2009). Oil price shocks and monetary policy aggregates in Nigeria: A structural VAR approach. Munich Personal RePEc Archive, 45-56.

Mordi, C. N. O. \& Adebiyi, M. A. (2010). The Asymmetric effects of oil price shocks on output and prices in Nigeria using a structural VAR model. Central Bank of Nigeria Economic and Financial Review, 48(1), $1-32$.

Ngalawa, H. \& Viegi, N. (2011). Dynamic effects of monetary policy shocks in Malawi. South African Journal of Economics, 79(3), 244-250.

Obinyeluaku, M. \& Viegi, N. (2012). Fiscal policy for managing oil revenues in Nigeria. Economic Research of South Africa. Working paper No. 2.

Obinyeluaku, M. I. (2009). Testing the fiscal theory of price level in Nigeria", University of KwaZulu-Natal Discussion Papers Series, No. 58.

Olasunkanmi, O. I. \& Babatunde, O. A. (2013). Empirical analysis shocks and current account dynamics in Nigeria. African Research Review, 7(1).

Olomola, P. (2006). Oil wealth and economic growth in African oil exporting countries. A.E.R.G Research Paper, $170,23-45$.

Papademous, L. (2008). The contribution of monetary policy to economic growth. European Central bank Conference Paper.

Peersman, G. \& Smet, F. (2002). The industry effects of monetary policy in the Euro-Area. European Bank Working Paper, 65, 34-56.

Sidrauski, M. (2003). Rational choice and patterns of growth in a monetary economy. American Economic Review, 57(2), 534-544.

Sims, C. A. (1980). Are forecasting models usable for policy analysis? Quarterly review of Federal Reserve Bank of Minneapolis, 10(1), 2-16.

Tobin, J. (1965). Money and economic growth, Econometrica, 33, 671-684.

Usenobong, F. A. \& Johnson, A. A. (2015). Macroeconomic effects of fiscal policy shock in Nigeria: A SVAR approach. International Journal of Business and Economics Research, 4(3), 109-120.

Uhlig, H. (2005). What are the effects of monetary policy on output? Results from an agnostic identification procedure. Journal of Monetary Economics, 52(6), 381-419.

Vonnak, B. (2005). Estimating the effects of Hungarian monetary policy within a structural VAR framework. Magyar Nemzeti Bank Working Paper Series, 1, 1-37.

World Bank. (2012). A review of monetary policy administration in Africa. World Bank Policy Research Paper, No. 2225. 